\title{
THE PROCEDURES OF AVIATION ACCIDENTS INVESTIGATION. THE HUMAN FACTOR AS A GREATEST AVIATION SAFETY THREAT
}

\begin{abstract}
Statistics show that air transport is the safest mode of transport in the world. However, it should be remembered that it is also the most expensive form of transport. Complicated safety procedures, expressed inter alia in prevention related to the prevention and investigation of aviation events, place the greatest emphasis on the human factor in aviation. Maintaining the reliability ratio in air transport at a sufficiently high level, with the current increase in air transport, is a priority. This requires integrated activities of all entities involved in aviation activities.

Aviation security is a general concept. Firstly, it covers problems related to operational safety (safety area). Secondly, protection problems of means of air transport and airport infrastructure protection against acts of unlawful interference (security area). The basic goal of aviation safety is to prevent all events related to the use of aircraft.

One of the directions aimed at increasing aviation safety was the development and an implementation of the concept of a safety management system, which includes subsystems: processing and analysis of collected information enabling current examination of safety status, trends of changes and threat forecasts, assessment of the effectiveness of preventive and rescue projects, a bank of knowledge about events, exposures, safety status and the impact of individual factors on safety.

Today we can say that a high security level has been achieved in air transport, as well as in services and in aviation training. It became possible due to the intensive, systematic and continuous work of aviation authorities and organizations.
\end{abstract}

Keywords: aviation, catastrophe, commission, security, transport.

\section{INTRODUCTION}

Considering threats in the security environment or in the system, attention should be paid to their evolution. There are new threat types, mainly with non-military nature, such as, for example: communication disasters, technical failures, natural disasters, environmental contamination that may have unpredictable consequences.

\footnotetext{
${ }^{1}$ Associated Prof. Jan Rajchel PhD., Insititute of Social and Security Studies, Department of Humanities, Siedlce University of Natural Sciences and Humanities, Konarskiego 2, 08-110 Siedlce; e-mail: jan.rajchel@wp.pl. ORCID: 0000-0001-7248-3863.

Dr hab. Jan Rajchel, prof. UPH, Wydział Humanistyczny, Uniwersytet Przyrodniczo-Humanistyczny w Siedlcach, ul. Konarskiego 2, 08-110 Siedlce; e-mail: jan.rajchel@wp.pl. ORCID: 0000-0001-7248-3863
} 
Taking into consideration contemporary security typology, it can be concluded that researchers attach too little importance to the transport safety threats, despite the fact that the number of traffic accidents victims is frightening ${ }^{2}$. According to the World Health Organization (WHO) statistics, since 1896, when the first fatal accident was reported as a result of a traffic accident, 35 million people died worldwide. However, of all modes of transport, air transport is considered to be the safest. 3.4 billion passengers used air transport in 2015 and the number of air operations in the world exceeded 34 million. This year is considered to be one of the safest in civil aviation. According to the Aviation Safety Network report, in the 16 air disasters in commercial air transport in 2015, a total of 560 people were died. The most tragic events in 2015 were an A320 aircraft crash in the French Alps, resulting in the deaths of 150 people and a bomb explosion aboard the Russian A321 aircraft in Egypt. In this accident 224 people died. On the other hand, in the safest year in the history of modern aviation, 2013, 265 people died in air accidents. In the commercial aviation history, there were also accidents where no one died. For example, the memorable US Airways Airbus A320 water landing on the Hudson River in 2009. All 155 people on board survived. Another example is the famous flight of Capt. Wrona, November 1, 2011 who landed Boeing 767 without a chassis at the F. Chopin airport in Warsaw.

Statistics show that the death probability in an aviation accident is 1:29 million. It is definitely "easier" to die on the ground than in the air. From 1997, the average number of aviation accidents shows a permanent and lasting fall. It is happening due to international aviation organizations efforts, such as: IATA (International Air Transport Association), ICAO (International Civil Aviation Organization) and the other organizations that create aviation security policy.

So that, an aircraft (an airplane, a helicopter) is considered to be the safest mode of transport. Accidents and other aviation incidents are rare, but despite the increasingly sophisticated aviation techniques, they cannot be completely eliminated. They can only be minimized.

The terrorist attack, which scares many passengers, is a rare phenomenon. According to current statistics, in the last decade there is one terrorist attack attempt per over 16 million flights. Despite, aviation protection against unlawful interference, sabotage, terrorist attacks and other acts of violence, is a serious problem faced by airport managing bodies, aircraft operators, state authorities and all services responsible for aviation safety.

Aviation security is a general concept. Firstly, it covers problems related to operational safety (safety area). Secondly, protection problems of means of air transport and airport infrastructure protection against acts of unlawful interference (security area). The aviation safety division into two areas has its justification, due to other risk assessment principles. Safety is mainly related to the state of safety achieved and maintained in aviation in the areas of aircraft construction, personnel selection and training, flight operations, safety management in aviation organizations and several other areas. The main focus has been put onto ways to counteract threats and reduce risk (hazard/risks). The second meaning (security) refers to the aviation protection against acts of unlawful interference and includes problems of ensuring the air transport system safety against conscious and harmful external interference ${ }^{3}$.

\footnotetext{
2 Due to WHO data, in road traffic accidents yearly die about $1,2 \mathrm{mln}$ people, http://pl.wikipedia.org/wiki/Kategoria:Katastrofy_drogowe (access: 12.12.2013 r.).

3 J. Karpowicz, E. Klich, Zarządzanie bezpieczeństwem w lotnictwie, Dęblin 2011, s. 8.
} 
The aviation incidents investigation is a process leading to the ascertainment of their actual causes, aimed at preventing aviation accidents and incidents in the future. This process consists of collecting, registering and analyzing materials containing relevant information to ascertainment the circumstances, course and causes of the occurrence, and developing preventive recommendations. This activity is not aimed at ascertaining the extent of anyone's fault or liability. The Commission investigating an aviation incident performs only the research function, ascertainment the cause of the incident and propose preventive actions. It does not have a disciplinary function.

\section{AVIATION INCIDENTS INVESTIGATION}

The aviation incidents investigation is regulated by international, regional (European), national and departmental regulations. Aviation is not a monolith, however, and there are some differences in the aviation incidents investigation. It is widely accepted that aviation is divided into state and civilian. This division outcome from the purpose and aircraft use. State aircrafts are used to describe aircraft used in military, police and customs services. However, all other types of aviation are civil (formerly private). It includes commercial (communication) and general aviation (General Aviation - GA). The division of aviation into civil and state can be find in international aviation law (the Convention on International Civil Aviation also known as the Chicago Convention) of December 7, 1944 4 .

The Chicago Convention is a multilateral international agreement, regulating international functioning of the civil aviation by introducing uniform standards in this field. These are published in the form of recommended practices and recommended methods of conduct in annexes to the Convention ${ }^{5}$. This Convention, in addition to other areas, regulates the investigation of aviation accidents and other aviation incidents. It should be noted that the Chicago Convention applies to civil aircrafts, and only in a limited extent to state aircrafts. Article 26 indicates that the aviation accidents investigation in accordance with the provisions of the Convention applies only to civil aviation. In case of investigating accidents in state aviation, national law applies.

Individual states national law in the area of accidents and other aviation incidents investigation may not contradict the legal norms of international law, but should refer to international provisions or should clarify them, but cannot change them.

General rules of aviation accidents in civil aviation investigation, in accordance with art. 26 are included in Annex No. 13, entitled "Aircrafts accidents and incidents investigation". It was accepted for the first time on April 11, 1951 and it has been changed many

${ }^{4}$ Dz.U. z 1959 r., nr 35, poz. 212 ze zm. Signed in Chicago, that is why it is co-called "Chicago Convention".

${ }^{5}$ Standard - any provision regarding physical characteristics, configuration, material, action, personnel or procedure whose homogeneous application has been deemed necessary for the protection or regularity of international air navigation and to which contracting States comply in accordance with the Convention. If it is not possible to comply with the standard, there is an obligation to notify the ICAO Council in accordance with the provisions of Article 38 of the Convention.

Recommended practice - any provision regarding physical characteristics, configuration, material, action, personnel or procedure whose harmonized use has been deemed desirable in the interest of airworthiness or efficiency of international air navigation and compliance with which will be the purpose of Contracting States in accordance with the provisions of the Convention. 
times - currently the 10th edition of 2010 is in force. International regulations established by ICAO also influenced to the formation of the air accident investigation system in the Member States of the European Union. The Chicago Convention's regime is the starting point for implementing the relevant regulations in national or regional legislation. Annex (No. 13) is a fairly general document and does not contain detailed procedures for investigating aviation accidents. Individual states can decide and should develop national documents (procedures) for safety investigation based on general guidelines. The Annex contains in particular: definitions, purpose of accident investigation, material evidence security. What is more, we can find there scope of responsibility of the state where accident took place, participation and responsibility of the State of Registry, State of Design, State of Manufacture, and State of the Operator ${ }^{6}$, preparation and publication of the preliminary and final report. Annex 13 states that the only the purpose of investigating aviation accidents and incidents shall in no case be concerned with apportioning blame or liability ${ }^{7}$

The accidents and other aviation incidents investigation shall be carried out by the State in whose territory the accident took place (State of the Occurrence). This State must conduct it in accordance with the international standards specified in the cited annex. It shall take all necessary steps to protect evidence and adequate protection of the aircraft and its contents for the time of the investigation. This evidence protection includes the preservation, by photographing or other means, of any evidence that could be removed, obliterated, lost or destroyed. Safe custody also includes protection against further damage, unauthorized access, theft and destruction (chapter 2, item 3.3 of Annex 13). If there is a request sent by the State of Registry, the State of the Operator, the State of Manufacture for the aircraft and the content of the aircraft, all other evidence shall remain untouched until it has been examined by the authorized representative of the State which made such a request, the State of Occurrence shall comply with such request as far as possible and not interfere with the proper conduct of the investigation. For the purpose of saving persons, animals, reaching out mail and valuables or to protect against damage by fire or other factors, or to avoid threats to other aircraft, means of transport or people, it is allowed to move the aircraft. When the aircraft and its contents are no longer needed for testing, the State of Occurrence should relieve them from the custody and pass them on to the owner. It also has the obligation to facilitate access to the aircraft, its contents and all its parts. If that the aircraft, its contents or parts are in an area where access is considered as impossible, the State of the Occurrence itself shall move the aircraft, aircraft's parts and contents to a accessible place. The following organizations (entities): the State of Registration, the State of Operator, the State of Manufacture, the State of Design and ICAO shall be notify about occurred aviation incident by the State of Occurrence.

In an aviation accident investigation, accredited representatives of the State of Registration (operator, designer or manufacturer) may participate, along with accompanying advi-

\footnotetext{
${ }^{6}$ State of Design. The State having jurisdiction over the organization responsible for the type design. State of Manufacture. The State having jurisdiction over the organization responsible for the final assembly of the aircraft.

State of Occurrence. The State in the territory of which an accident or incident occurs.

State of the Operator. The State in which the operator's principal place of business is located or, if there is no such place of business, the operator's permanent residence.

State of Registry. The State on whose register the aircraft is entered.

${ }^{7}$ Annex 13, definitions, chapter 1.
} 
sers. They can participate every investigation step and can making statements regarding the investigation. It is the responsibility of the accredited representative and their advisers to provide any information they have in order to assist the investigative State Committee. After notification's receiving, concerned States shall, as soon as possible, notify the State of Occurrence of any relevant information about the crew and aircraft that has suffered an accident or serious incident, as well as hazardous materials, if they were on board. Each of the states involved informs the State of Occurrence whether it intends to appoint an authorized representative who can legally participate in the investigation. An authorized representative shall be appointed at the express request of the State conducting the aircraft accident investigation, when aircraft's weight exceeds $2250 \mathrm{~kg}$.

If the investigation is carried out in whole or in part by another state or regional accident investigation organization, it is expected that this country will be responsible for conducting the investigation, including drafting the final report.

If an accident or serious aircraft incident has occurred on the territory of a State which is not a part of the Chicago Convention and it does not intend to carry out investigation in accordance with Annex 13, the State of Operator should seek to initiate and conduct the investigation in cooperation with the State of Occurrence or on its own, using the information having at its disposal. However, if an accident or serious incident has occurred in a territory that is not within the jurisdiction of any State or over international waters, the State of Registry (owner's state) initiates and conducts the investigation of this incident on its own or can delegate, in whole or in part, conducting the investigation to another state based on mutual agreement and consent. The nearest countries to site that accident has occurred in international waters, should provide assistance that is within their scope ${ }^{8}$.

The accident investigation authority is independent in conducting the investigation and has unlimited powers to conduct it. Each investigation carried out in accordance with the provisions of Annex 13 shall be separate from any judicial or administrative proceedings leading to adjudicate of guilt or liability. The accidents other aviation incidents investigation is carried out by experts from the state accident investigation authority (commission). Conducting any court or administrative proceedings is carried out by judicature experts. However, the need for coordination between the head of the investigation team and judicial authorities is necessary. Special care is devoted to evidence that is used by both parties and requires immediate registration and analysis to complete the investigation. This applies to victims examination and identification and the read out flight recorders' data. Activities coordination between the research team and the judicature may be necessary at the scene of the accident and during the factual information's gathering. The investigating State acknowledges necessity of coordination between the chair of the research team and the judicature.

The authority examining an aircraft accident or incident shall collect and process documents related to the occurrence such as: statements of persons obtained during the survey, correspondence between persons involved in the operation of the aircraft, medical data concerning persons involved in the accident or incident, cockpit voice recordings and their transcripts, records and transcripts of entries from air traffic control units, cockpit video records (if any), opinions made in the information analysis, including information from flight recorders. These documents are included in the final report or its additions only, if

\footnotetext{
8 Vide Annex 13 chapter. 5...
} 
they relate to the analysis an accident or incident. Documents not relevant to such analysis are not disclosed.

During any aviation incident investigation conducted in accordance with the provisions of Annex 13, there must be unrestricted access to all evidence and the investigation shall not be obstructed by administrative or judicial investigations. This must be guaranteed by national legislation or agreements between accident investigation authorities and judicial authorities. If new and valid evidence emerges at the end of the study, the country that conducted the study may resume it.

In the accident or incident investigation, flight data recorders are effectively used. In case, when the State conducting the accident or incident investigation does not have the appropriate equipment to read out the flight data recorders, it should use the devices made available by other States, factoring in the following aspects: the capabilities of reading devices; timeliness of reading; and location of reading devices.

Reading out flight recorders one of the most important action in the examining aviation accidents process. It is important to find and read out flight recorder parameters, and one of the most urgent decisions is to choose the place of reading and analyzing data flight data recorders. It is important to read out the flight parameter recorders as soon as possible after the accident. Quick areas problem's identification can affect the examination, at the scene of an accident, where the evidence is sometimes impermanent. Quick identification of problem areas can also result in the efficient issuing of security recommendations that may be necessary to prevent similar incidents. Many countries do not have their own devices to read out and analyze information from on-board recorders (both sound and data) and, therefore, they solicit other countries for help. The manufacturer's standard equipment and software, usually used in airlines or maintenance facilities, is not considered appropriate for the examination. If the recorders have been damaged, special data recovery and analysis techniques are usually necessary.

The State of Manufacture (or the State of Design) is responsible for the airworthiness and has the appropriate facilities, normally required to read out and analyze information from the flight data recorder. Since the flight recorder information may reveal airworthiness problems, the manufacturer's (or constructor's) country should have its representative present when reading out and analyzing the data from the recorder.

Flight data recorder and cabin sound recorder's records should be read out in the same place as they contain mutually complementary data. This can help verifying each record, as well as in setting out the order of events and their synchronization over time. Flight data recorders cannot be opened or powered, and original records should not be copied before reading due to the risk of damage.

Institution where for another country recorders are reading out, should be able to comment on the final report in order to ensure that the analysis of entries has been taken into account. The institution may request specialized assistance from the manufacturer or aircraft operator to obtain data for calibration and verification of recorded information. Until the investigation is completed, the investigating State may retain original records or copies thereof in the reading out institution, for explanation purposes, provided that the institution has appropriate security procedures to ensure that these records are protected.

The State conducting an fatality accident investigation organizes a full body necropsy and, in special circumstances, corpses of passengers and deck crew by an anatomist who has experience in accident investigation. Necropsies should be carried out immediately and to the full extent. 
A State of Occurrence conducting an accident or incident investigation may delegate this test to another State or regional organization appointed to investigate aviation accidents. At the request of the State conducting the investigation, each State may provide it with information, facilities or experts. Such a state has the right to appoint an authorized representative to participate in this examination, and to appoint one or several advisers to assist the authorized representative. This does not mean that the State conducting an accident investigation has no right to appoint its own technical experts from any organization and designate them as advisers to its representatives. Advisors are authorized to participate in the research to the necessary extent. Participation in the research entitles them to participate in all research processes under the chair of the research team's supervision. In particular they can: go to the scene of the accident, examine the remains, obtain information from witnesses and propose the interview's scope, having full and immediate access to relevant evidences, obtain copies of all relevant documents, participation in the reading out of registered materials, participation in research activities outside the accident site, such as part testing, technical presentations, tests and simulations, participation in meetings related to the progress of the study, including discussions related to analysis, findings, causes and recommendations for security, the submission of proposals for the various elements of the study ${ }^{9}$.

The State conducting an accident investigation shall draft a final report, which shall be sent to the interested parties (State of Registration, State of Operator, State of Manufacture, State of Desin and each country that participated in the investigation) with a request to refer to it and submit comments as fast as it possible. The State conducting the accident or incident investigation as soon as possible and, if possible within 12 months, shall make the final report publicly available. The State which carried out the investigation of the aircraft accident or incident with a maximum mass more than $5700 \mathrm{~kg}$ and issued the final report shall send a copy to the International Civil Aviation Organization ${ }^{10}$.

At any stage of the accident or incident's investigation, the investigating authority may make recommendations which prompt execution is considered to be necessary in order to increase the aviation safety's level. Recommendations resulting from aviation accident and incident investigations are addressed by means of dated correspondence to accident investigation bodies of other countries and to ICAO. Main part of the final report includes the following chapters: factual information, analysis results, final conclusions from the study, safety recommendations.

Safety information must be protected against loss and improper use. The term "misuse of information" should be understood as the use of safety information for purposes other than those for which it was collected, i.e. the use of information in disciplinary, civil, administrative and criminal proceedings against operating personnel, and / or making them public (point 1.1 of Annex E). The only purpose of protecting safety information against misuse is to ensure its uninterrupted availability so that timely and appropriate preventive action can be taken and improved aviation safety. Reports on accident and other aviation incidents should be available to aeronautical organizations and other authorized persons for purposes related to future security. In accordance with the recommendations of Annex 13, countries are required to enforce laws protecting the information collected in the Safety Data Collection and Processing Systems (SDCPS). The information collected in this system should be used primarily to improve aviation safety.

\footnotetext{
9 Vide art. 5.25 Annex 13...

${ }^{10}$ Ibidem, chapter. 6, art. 6.1-6.7.
} 
National legal acts and ordinances connected to protecting safety information should ensure a compromise between the need to protect information and the needs of the justice system. The use of information in disciplinary, civil, administrative or criminal proceedings should only take place under appropriate safeguards guaranteed by national law. In justified cases, national law should allow the possibility of deviations from the rules for the protection of safety information, e.g. if there is evidence that an aviation incident was caused intentionally to cause damage or is grossly negligent or non-compliant with professional ethics.

\section{SAFETY MANAGEMENT SYSTEM}

Currently, one of the most important problems of air transport is to ensure the highest safety level, that is why aviation structures are improved, develops navigation systems and air traffic control, improves methods of air traffic management and aviation organizations, increases the requirements for professional qualifications of operational personnel (pilots, controllers, ground maintenance mechanics). Maintaining the reliability ratio in air transport at a sufficiently high level, with the current increase in air transport, is a priority. This requires integrated activities of all entities involved in aviation activities. The basic goal of aviation safety is to prevent all incidents related to the aircraft use. As the statistics of accidents and serious aviation incidents show, the weakest link in the aviation safety system is man and, above all, man's tendency to make mistakes. In aviation, it is recognized that almost all aviation events occur as a result of some human error, which often does not have a simple reference to the very use of the aircraft. Therefore, measures to prevent aviation accidents should cover all aspects of human participation in the use of aircraft, and not only those that seem to be the most obvious.

The high aviation safety level results achieved today are mostly explained by the work on the consequences or symptoms of human action. If, as a result of such work, it turned out that such or other activities may become the cause of security threats, then new methods, procedures and legal provisions are developed in order to avoid or minimize their consequences. In order to reduce the failure rate or maintain it at the current level, it is necessary to go beyond the framework of work on the human action's consequences In other words, the desire to detect and understand the causes that caused adverse reactions or behavior of the person should be significantly activated. Only then will one expect a radical improvement in flight safety indicators. It is much more difficult to anticipate human actions and reactions and to influence their change than to consider their consequences.

One of the directions aimed at increasing aviation safety was the development and implementation of the concept of a safety management system, which includes subsystems: (1) processing and analysis of collected information enabling current examination of safety status, trends of changes and threat forecasts; (2) assessment of the effectiveness of preventive and rescue projects; (3) a bank of knowledge about events, exposures, safety status and the impact of individual factors on safety.

Nowadays we can say that a high level of security in air transport has been achieved, as well as in services and in aviation training. It became possible due to the intensive, systematic and continuous work of aviation authorities and organizations, as well as political and economic organizations such as the European Union, which became the creator of very significant changes in aviation through political and legal actions. 
Safer flying has also been achieved due to the modern aircraft's high reliability, the development of air traffic control systems and airport equipment. Implementation areas of high safety standards have been extended to include aircraft design and construction processes, personnel selection and training, aviation procedures and regulations, air traffic control systems, and the operation of all aviation safety services. Aviation companies, namely their activities resulting from their destination and in the safety sector are the subject of supervision, control and continuous monitoring. The activities of committees investigating the reasons for their occurrence are of great importance in the prevention of aviation accidents. Based on the results of accident and incident investigation, recommendations and proposals are developed to prevent similar events in the future. The most attention in the prevention of flight safety is still devoted to man, in every position - in the aircraft cabin, behind the air traffic control radar indicator, in direct ground service, in production and renovation plants. Man remains the most unreliable link in the aviation system. That is why the system of training, granting qualifications, refreshing knowledge and competence is so important.

The investigation of aviation incidents is a process leading to the ascertainment of their actual causes, aimed at preventing future accidents and incidents. This process consists of collecting, registering and analyzing materials containing relevant information to determine their circumstances, course and causes of the event, and developing preventive recommendations. This activity is not aimed at ascertainment the extent of anyone's fault or liability.

Today we can say that a high security level has been achieved in air transport, as well as in services and in aviation training. It became possible due to the intensive, systematic and continuous work of aviation authorities and organizations, as well as political and economic organizations such as the European Union, which became the creator of very significant changes in aviation through political and legal actions.

\section{RESUME}

The aviation incidents investigation is regulated by international, regional (European), national and departmental regulations. Aviation is not a monolith, however, and there are some differences in the aviation incidents investigation. It is widely accepted that aviation is divided into state and civilian. This division outcome from the purpose and aircraft use. State aircrafts are used to describe aircraft used in military, police and customs services. However, all other types of aviation are civil (formerly private). It includes commercial (communication) and general aviation (General Aviation - GA). The division of aviation into civil and state can be find in international aviation law (the Convention on International Civil Aviation also known as the Chicago Convention) of December 7, 1944.

The Chicago Convention is a multilateral international agreement, regulating international functioning of the civil aviation by introducing uniform standards in this field. These are published in the form of recommended practices and recommended methods of conduct in annexes to the Convention. This Convention, in addition to other areas, regulates the investigation of aviation accidents and other aviation incidents. It should be noted that the Chicago Convention applies to civil aircrafts, and only in a limited extent to state aircrafts. Article 26 indicates that the aviation accidents investigation in accordance with the provisions of the Convention applies only to civil aviation. In case of investigating accidents in state aviation, national law applies. 
Currently, one of the most important problems of air transport is to ensure the highest safety level, that is why aviation structures are improved, develops navigation systems and air traffic control, improves methods of air traffic management and aviation organizations, increases the requirements for professional qualifications of operational personnel (pilots, controllers, ground maintenance mechanics). Maintaining the reliability ratio in air transport at a sufficiently high level, with the current increase in air transport, is a priority. This requires integrated activities of all entities involved in aviation activities. The basic goal of aviation safety is to prevent all incidents related to the aircraft use. As the statistics of accidents and serious aviation incidents show, the weakest link in the aviation safety system is man and, above all, man's tendency to make mistakes. In aviation, it is recognized that almost all aviation events occur as a result of some human error, which often does not have a simple reference to the very use of the aircraft. Therefore, measures to prevent aviation accidents should cover all aspects of human participation in the use of aircraft, and not only those that seem to be the most obvious.

As statistics show air transport is the safest mode of transport in the world. However, it should be remembered that it is also the most expensive form of transportation. Complicated safety procedures, expressed inter alia in prevention related to the prevention and investigation of aviation events, place the greatest emphasis on the human factor in aviation. Maintaining the reliability ratio in air transport at a sufficiently high level, with the current increase in air transport, is a priority. This requires integrated activities of all entities involved in aviation activities. The aviation safety's main goal is to prevent all incidents related to the use of aircraft.

\section{REFERENCES}

1. Karpowicz J., Klich E., Zarządzanie bezpieczeństwem w lotnictwie, WSOSP, Dęblin 2011.

2. National Aviation Safety Programme (Krajowy Program Bezpieczeństwa w Lotnictwie Cywilnym), ULC, Warszawa 2016.

\section{LEGAL ACTS}

1. Konwencja o międzynarodowym lotnictwie cywilnym (Dz.U. z 1959 r., nr 35, poz. 212 ze $\mathrm{zm}$.).

2. Council Directive 80/1266/EEC of 16 December 1980 on future cooperation and mutual assistance between the Member States in the field of air accident investigation.

3. Council Directive 94/56/EC of 21 November 1994 establishing the fundamental principles governing the investigation of civil aviation accidents and incidents.

4. Regulation (EU) No 996/2010 of the European Parliament and of the Council of 20 October 2010 on the investigation and prevention of accidents and incidents in civil aviation and repealing Directive 94/56/EC.

5. Commission Regulation (EC) No 622/2003 of 4 April 2003 laying down measures for the implementation of the common basic standards on aviation security.

6. Regulation (EC) No 1592/2002 of the European Parliament and of the Council of 15 July 2002 on common rules in the field of civil aviation and establishing a European Aviation Safety Agency

7. Ustawa z dnia 3 lipca 2002 r. - Prawo lotnicze (tekst jedn. Dz.U. z 2018 r., poz. 1183). 
8. Zarządzenie Ministra Transportu z dnia 30 czerwca 2006 r. w sprawie regulaminu działania Państwowej Komisji Badania Wypadków Lotniczych.

9. Rozporządzenie Ministra Transportu z dnia 18 stycznia 2007 r. w sprawie wypadków i incydentów lotniczych (tekst jedn. Dz.U. z 2017 r., poz. 1995).

10. Annex 13 - Aircraft Accident and Incident Investigation to Chicago Convention on International Civil Aviation, edition 10, 2013.

\title{
INTERNET SOURCES
}

1. http://pl.wikipedia.org/wiki/Kategoria:Katastrofy_drogowe (dostęp: 12.12.2013 r.).

\section{PROCEDURY BADANIA WYPADKÓW LOTNICZYCH. CZYNNIK LUDZKI, JAKO NAJWIĘKSZE ZAGROŻENIE BEZPIECZEŃSTWA W LOTNICTWIE}

\begin{abstract}
Jak pokazują statystyki, transport lotniczy to najbezpieczniejszy środek transportu na świecie. Pamiętać jednak należy, że jest jednocześnie najdroższą formą transportu. Skomplikowane procedury bezpieczeństwa, wyrażone między innymi profilaktyką związaną z zapobieganiem i badaniem zdarzeń lotniczych największy nacisk kładą na czynnik ludzki w lotnictwie. Utrzymanie współczynnika bezawaryjności w transporcie powietrznym na odpowiednio wysokim poziomie, przy obecnym wzroście przewozów lotniczych, jest sprawą priorytetową. Wymaga to zintegrowanych działań wszystkich podmiotów zaangażowanych w działalność lotniczą. Bezpieczeństwo lotnictwa jest pojęciem o charakterze ogólnym. Obejmuje ono problemy związane z bezpieczeństwem operacyjnym (safety) oraz problemy ochrony środków transportu lotniczego, infrastruktury lotniczej przed aktami bezprawnej ingerencji (security). Drugie znaczenie (security) odnosi się do ochrony lotnictwa przed aktami bezprawnej ingerencji i obejmuje problemy zapewnienia bezpieczeństwa systemu transportu lotniczego przed świadomą i szkodliwą ingerencją z zewnątrz.

Jednym z kierunków zmierzających do zwiększenia bezpieczeństwa było opracowanie i wdrożenie koncepcji systemu zarządzania bezpieczeństwem, który obejmuje podsystemy: przetwarzania i analizy zebranych informacji umożliwiających bieżące badanie stanu bezpieczeństwa, tendencji zmian oraz prognozy zagrożeń; oceny skuteczności przedsięwzięć profilaktycznych i ratowniczych; bank wiedzy o zdarzeniach, narażeniach, stanie bezpieczeństwa oraz o wpływie poszczególnych czynników na bezpieczeństwo.

Dziś możemy powiedzieć, że obecnie osiągnięto wysoki poziom bezpieczeństwa w transporcie lotniczym, a także w usługach i w szkoleniu lotniczym. Stało się to możliwe dzięki wytężonej, systematycznej i ciągłej pracy władz i organizacji lotniczych, a także organizacji polityczno-gospodarczych takich jak Unia Europejska, która stała się kreatorem bardzo istotnych zmian w lotnictwie poprzez działania polityczno-prawne.
\end{abstract}

Słowa kluczowe: lotnictwo, katastrofa, komisja, bezpieczeństwo, transport.

DOI: $10.7862 / \mathrm{rz} .2018 . \mathrm{mmr} .52$

Tekst ztożono do redakcji: lipiec $2018 r$. Tekst przyjęto do druku: grudzień $2018 \mathrm{r}$. 
